\title{
Cassava (Manihot esculenta Crantz) Tuber Quality as Measured by Starch and Cyanide (HCN) Affected by Nitrogen, Phosphorus, and Potassium Fertilizer Rates
}

\author{
I. B. Cuvaca ${ }^{1}$, N. S. Eash ${ }^{1}$, S. Zivanovic ${ }^{2}$, D. M. Lambert ${ }^{3}$, F. Walker ${ }^{1} \&$ B. Rustrick ${ }^{4}$ \\ ${ }^{1}$ Department of Biosystems Engineering \& Soil Science, University of Tennessee Institute of Agriculture, \\ Knoxville, Tennessee, USA \\ ${ }^{2}$ Department of Food Science and Technology, University of Tennessee Institute of Agriculture, Knoxville, \\ Tennessee, USA \\ ${ }^{3}$ Department of Agricultural \& Resource Economics, University of Tennessee Institute of Agriculture, Knoxville, \\ Tennessee, USA \\ ${ }^{4}$ Eastern Produce Kenya Ltd, Nandi Hills, Kenya \\ Correspondence: N. S. Eash, Department of Biosystems Enginnering and Soil Science, University of Tennessee \\ Institute of Agriculture, 2506 E. J. Chapman Drive, Knoxville, TN 37996-4531, USA. Tel: 1-865-974-7134. \\ E-mail: eash@utk.edu
}

Received: March 10, 2015 Accepted: April 8, 2015 Online Published: May 15, 2015

doi:10.5539/jas.v7n6p36 URL: http://dx.doi.org/10.5539/jas.v7n6p36

\begin{abstract}
Cassava (Manihot esculenta Crantz) is an important subsistence crop for many poor rural families in Africa. Cassava contains cyanogenic glucosides (linamarin and lotaustralin) which liberate hydrogen cyanide (HCN) during tuber processing. Once liberated, $\mathrm{HCN}$ attaches to the processed tuber. Continuous consumption of processed tuber containing high $\mathrm{HCN}$ concentration coupled with low protein intake causes Konzo - a paralyzing disorder that impacts children and women of childbearing age. There are ways to reduce HCN concentration during tuber processing; however, this can also reduce the overall starch content in the cassava tuber. A study comprising twenty treatments consisting of different combinations of nitrogen (N), phosphorus (P), and potassium (K) fertilizer rates was initiated in 2013 in the coastal Dondo District of Mozambique to assess cassava tuber quality as measured by starch and HCN. Significant differences were observed in starch content (CSC) of unprocessed tubers due to combined addition of N, P and K fertilizer rates, sample size, and estimation procedure. However, no significant differences were observed in HCN concentration in tubers due to the addition of N, P and K fertilizer. The HCN concentration in cassava tuber appears to be a function of the physiology of the crop or possibly cassava variety rather than the environment or conditions under which the crop is grown.
\end{abstract}

Keywords: cassava, cassava quality, cyanide, fertilizer, rate, starch

\section{Introduction}

Cassava (Manihot esculenta Crantz) is a perennial tuber crop that originated in South America (Hillocks et al., 2002a). Cassava is a major staple and an important source of calories to more than half a billion people in Africa, Asia, and Latin America (Rosenthal \& Ort, 2011; FAO, 2013). Its introduction in Africa dates back to the 1550s. Today Africa is the foremost cassava producing region with over half of the global production (FAO, 2013).

Cassava was introduced in Mozambique in the 1750s (Benesi, 2005). Today Mozambique is the fifth largest producer of cassava in Africa and second only to Angola in Southern Africa with an estimated average annual yield of $\sim 6$ tons per ha (Dias, 2012). Cassava production is mostly confined to nutrient-depleted soils and small scale resource-poor farmers (El-Sharkawy, 2004) who farm less than 4 hectares (Gwarizimba, 2009). Cassava is a major food crop and the second most important crop in Mozambique following maize (Ministério da Indústria e Comércio/Direcção Nacional do Comércio, 2007). According to Gwarizimba (2009), cassava contributes 6 percent of the country's GDP and 45 percent of the diet, approximately $628 \mathrm{kcal}$ per person per day (Promar Consulting, 2011).

Despite being ranked the fifth largest producer of cassava in Africa (FAO, 2011), cassava production in 
Mozambique can be severely limited due to two viral diseases: African Cassava Mosaic Disease (ACMD) and Cassava Brown Streak Disease (CBSD) (Hillocks et al., 2002b). CBSD was reported to be largely confined to the coastal regions of eastern and southern Africa. Recent proliferation of this disease (CBSD) has caused yield losses of up to 50 percent in the Northern provinces of Nampula and Zambezia, Mozambique (Promar Consulting, 2011) where cassava production is concentrated (Hillocks et al., 2002b).

Traditionally, cassava is grown in low input systems and nutrient-poor soils either in association with other crops (such as maize (Zea mays) and pigeon-pea (Cajanus cajan) (Hillocks et al., 2002a)) or as a sole crop, without any addition of fertilizer (El-Sharkawy, 2004) which leads to continuous mining of nutrients and subsequent soil degradation. Cassava is usually planted at the beginning of the rainy season but, unlike other crops, it (the leaves and tubers) can be harvested throughout the year as needed.

Cassava contains two cyanogenic glucosides (linamarin and lotaustralin) that liberate hydrogen cyanide (HCN) upon tissue disruption (Magnuson, 1997). Their presence in the plant, especially the tuber, has partly been associated with the poor conditions under which the crop is grown (Cardoso et al., 2005; Essers, 1988) with drought being one of the few parameters that has been investigated (de Bruijn, 1973; Nwosu \& Onofeghara, 1991). Cassava HCN protects the plant against animal and insect predation (Saunders, 2012) but it is also an important determinant of tuber quality and use. Based solely on the content of $\mathrm{HCN}$, cassava varieties are bitter (high $\mathrm{HCN}$, can reach $250 \mathrm{mg}$ per $\mathrm{kg}$ fresh matter or more) or sweet (low $\mathrm{HCN}, \sim 50 \mathrm{mg}$ per $\mathrm{kg}$ fresh matter) (FAO, 1977). Bitter varieties are more drought tolerant (Essers, 1988) and mainly used for famine relief and nonfood starch based industrial products such as paper, ethanol, thermobioplastics, and pharmaceuticals (FAO, 2006). Sweet cassava varieties are mainly used for food. Despite its sweetness, sweet varieties can still be dangerous to humans if poorly processed tubers are used for human consumption (Braidotti, 2011). According to Cardoso et al. (2005) and Braidotti (2011), continuous consumption of poorly processed cassava tubers and their products coupled with low protein intake cause Konzo - a chronic dietary disease caused by high cassava HCN that impacts mainly young women and children in poor cassava-producing countries in eastern Africa. Konzo victims are unable to walk, stand and, in severe cases, unable to speak (Braidotti, 2011). Blanching, washing, and fermentation (Nambisan, 2011) are three common methods used to lower cassava HCN present in the tubers (Lambri et al., 2013). Although these methods are very well diffused among cassava producing countries, the growing number of Konzo victims in eastern Africa raises questions on their effectiveness in lowering HCN. While it is mandatory to use blanching, washing and/ or fermentation to reduce cassava HCN concentration in the tubers if it is to be used for human consumption, these methods reduce the actual cassava starch content (CSC) which is another important element in defining cassava tuber quality. Cassava starch can be retained in the water during the processing; however, losses can be minimized by harvesting the starch retained in the water used for fermentation or blanching. To avoid underestimation of the actual CSC in the tubers, a real time in-field method called the Underwater Weight Method (ISI, 1999) was developed and made available for commercial use. However, to date, there is very little literature on studies undertaken to assess the relationship between cassava starch, HCN, and fertilizer rates. It is hypothesized that nutrient-depleted soils and smallholder farmer inability to replenish soil nutrients with mineral fertilizer are also associated with high concentrations of HCN and starch present in the tubers. To investigate this hypothesis, a no-till cassava fertilizer study was conducted to determine nitrogen $(\mathrm{N})$, phosphorous $(\mathrm{P})$, and potassium $(\mathrm{K})$ fertilizer rates for optimum cassava quality (low tuber HCN and high starch) for the coastal Dondo District of Mozambique. An underwater weight (International Starch Institute, 1999) and alkaline picrate (Sarkiyayi \& Argar, 2010) methods were used to estimate actual CSC (\%) and HCN levels, respectively.

\section{Method}

\subsection{Experimental Site}

The experiment was conducted at Milha-14 (19 $\left.25^{\prime} 54.0^{\prime \prime} \mathrm{S}, 34^{\circ} 43^{\prime} 28.6^{\prime \prime} \mathrm{E}\right)$, in the coastal Dondo District, central Province of Sofala, Mozambique, over the 2013/14 agricultural year. Mozambique is divided into ten provinces and an equal number of agro-ecological zones or regions (Ministry of Agriculture \& Fisherie, 1996). These agro-ecological zones are identified based on climate, soil type, elevation, and farming system (Maria \& Yost, 2006). Milha-14 falls within the agro-ecological region R5; which is suitable to very suitable for cassava production (MAF, 1996). R5 has low altitude ranging from 0-200 $\mathrm{m}$ above sea level, annual average temperature of $24{ }^{\circ} \mathrm{C}$, rainfall index ranging from 1,000 to $1,400 \mathrm{~mm}$, and soil texture ranging from sand to sandy loam. The soils at Milha-14 are relatively young, thus suggesting that they have been eroded and re-deposited by water. Field observations suggest that the soils at the site (Milha-14) are Inceptisols with a high water table at or near the surface for most of the year which prevents drainage and leads to near continuous waterlogging. The shallow depth at which reduced metal (iron and manganese) oxides occur suggests that an Aquept is the dominant 
suborder (Soil Survey Staff, 2010).

\subsection{Experimental Design and Management}

Twenty fertilizer treatments consisting of different combinations of contrasting N, P, and K rates (Table 1) were laid out in a completely randomized design (CRD) with four replicates each. Each fertilizer combination consisted of three nutrients total; two applied at fixed rates $(\mathrm{N}, \mathrm{P}$, and $\mathrm{K}$ fixed at 60,60 , and $150 \mathrm{~kg} / \mathrm{ha}$, respectively) and one (the one being tested) applied at varying rates. This was done to allow us to understand how changing each one of these fixed rates individually would affect our response variables if the remaining fixed rates were unchanged. A bitter cassava variety resistant to ACMD, Tapioca, was manually planted on untilled plots at a row by plant spacing of $1-\mathrm{m}$ by $1-\mathrm{m}(\sim 10,000$ plants per ha) to investigate the effect of combined application of $\mathrm{N}, \mathrm{P}$, and $\mathrm{K}$ fertilizer rates on $\mathrm{CSC}$ and $\mathrm{HCN}$ present in the tubers. Planting and fertilizer application were completed manually. Urea, single super phosphate, and potassium chloride were used as the N, P, and K sources, respectively. The N, P, and K were applied as basal fertilizer. Manual weeding was completed at the onset of the cropping season. Plants were harvested manually to avoid damaging the tubers, and the harvestable area (net plot) consisted of four plants harvested from two central rows (only) of a four row plot with four plants each (16 plants per plot total).

\subsection{Cassava Starch Content (CSC) Estimation Procedure and Assessment}

The CSC of fresh tubers was determined using a method known as the Underwater Weight Method (International Starch Institute, 1999), used in cassava commercialization to estimate the content of starch present in the tubers and its respective market price. This method is mostly used in areas lacking laboratory facilities and more sophisticated equipment for measuring starch; hence, it could be a good fit to small scale resource-poor farmers who grow cassava at Milha-14 - an area that still lacks basic infrastructure. The CSC was estimated by determining root (or tuber) specific gravity (SG). The middle portion of the tuber was selected, and SG was determined from tuber samples of approximately $3 \mathrm{~kg}$ or $3 \mathrm{~kg}$ and $5 \mathrm{~kg}$ depending on the below ground fresh tuber mass weight harvested from each plot by measuring the weight lost by peeled tubers submerged in water (if there was enough mass, both measurements were completed). CSC was estimated using three CSC estimation equations (below) used for estimating CSC in cassava commercialization. Estimates from each treatment were compared among themselves, and then assessed by comparison with the starch content estimates obtained from a parallel analysis run on a portion of eight samples randomly selected from each plot. The parallel analysis consisted of an enzymatic procedure known as the Megazyme Total Starch Procedure which has its basis on the AOAC Method 996.11 and AACC Method 76.13 with improvements (Megazyme International Ireland, 2011).

$$
\begin{gathered}
\operatorname{CSC}(\%)=(S G-1.00906) / 0.004845 \quad(\text { Sungzikaw, 2008) } \\
\operatorname{CSC}(\%)=(S G-1.01506) / 0.0046051 \text { (ISI, 1999) } \\
\operatorname{CSC}(\%)=(210.8 \times S G)-213.4 \text { (Khanthavong et al., 2012) }
\end{gathered}
$$

\subsection{Cassava Cyanide (HCN) Concentration Estimation Procedure}

To determine cassava HCN concentration present in the tubers, the samples were peeled, cleaned, chopped into approximately 3-mm slices, air/sundried first, and dried to a constant weight in an oven $\left(75^{\circ} \mathrm{C}\right.$ for 72 hours). Each sample was ground into flour and then homogenized with a No. 40 mesh sieve to ensure equal distribution of $\mathrm{HCN}$ in the sample. Subsequently, a $5 \mathrm{~g}$ subsample was drawn and each subsample was mixed with $50 \mathrm{~mL}$ distilled water and agitated for 16 hours $\left(35^{\circ} \mathrm{C}\right)$ in a shaking water bath. Extracts were then taken for analysis. The tuber HCN concentration was determined using a method with alkaline picrate (Sarkiyayi \& Argar, 2010). Cassava HCN concentration was determined by measuring absorbance at $490 \mathrm{~nm}$ using a spectrophotometer (UV-2101 PC, Shimadzu).

Similar to CSC (\%), results of cassava HCN concentration (mg per $100 \mathrm{~g}$ dry sample) analysis are reported on a dry weight basis (Table 1).

\subsection{Data Analysis}

Starch and cyanide data were analyzed using SAS 9.3, Cary NC. Statistical analyses were performed using ANOVA and means compared (Table 1) using LSD at $\alpha=0.05$.

\section{Results and Discussion}

The results of the two quality parameters analyzed in this study consist of (1) the estimate of the starch content (CSC\%) and (2) the concentration of HCN (mg per $100 \mathrm{~g} \mathrm{dw}$ ) present in the tubers as presented in Table 1. CSC estimates obtained using the Underwater Weight Method differed significantly due to fertilizer addition $(\mathrm{p}<0.05)$ except when a $3 \mathrm{~kg}$ sample size was used $(\mathrm{p}>0.05)$. Average estimates obtained using the $3 \mathrm{~kg}$ sample size 
revealed the highest CSC (65.9\%) for both treatments 3 and $17\left(0-60-90\right.$ and $60-60-90 \mathrm{~kg} / \mathrm{ha} \mathrm{N}-\mathrm{P}_{2} \mathrm{O}_{5}-\mathrm{K}_{2} \mathrm{O}$, respectively) and the lowest CSC $(44.2 \%)$ for treatment $10\left(60-0-150 \mathrm{~kg} / \mathrm{ha} \mathrm{N}-\mathrm{P}_{2} \mathrm{O}_{5}-\mathrm{K}_{2} \mathrm{O}\right)$ whereas average estimates obtained using the $5 \mathrm{~kg}$ sample size revealed the highest CSC (49.8\%) for treatment $13(60-90-150$ $\left.\mathrm{kg} / \mathrm{ha} \mathrm{N}-\mathrm{P}_{2} \mathrm{O}_{5}-\mathrm{K}_{2} \mathrm{O}\right)$ and the lowest CSC $(22.1 \%)$ for treatment 8 (75-60-150 kg/ha N-P $\left.\mathrm{P}_{2} \mathrm{O}_{5}-\mathrm{K}_{2} \mathrm{O}\right)$ (Table 1).

In general, an overall decreasing trend in CSC (\%) estimates was observed with increasing addition of $\mathrm{N}$ (treatments 5 through 9) for both $3 \mathrm{~kg}$ and $5 \mathrm{~kg}$ sample sizes (Figures 1 and 2), and increasing addition of $\mathrm{K}$ (Figure 1, treatments 14 through 20) for $3 \mathrm{~kg}$ sample size only. On the other hand, an increasing trend in CSC (\%) estimates was observed with increasing addition of $\mathrm{P}$ (Figures 1 and 2, treatments 10 through 13) for both sample sizes $(3 \mathrm{~kg}$ and $5 \mathrm{~kg}$ ). Previous studies showed that the above ground plant weight is directly related to $\mathrm{N}$ (Gardner et al., 1985; Chintala et al., 2012a; 2012b). Ukaoma and Ogbonnaya (2013) found similar results in that $\mathrm{N}$ fertilization must be effectively matched with sufficient $\mathrm{P}$ and $\mathrm{K}$ else yields can be depressed significantly. Therefore, excess $\mathrm{N}$ or adding $\mathrm{N}$ alone can favor more biomass production at the expense of tuber growth as added $\mathrm{N}$ may promote vegetative growth while simultaneously limiting carbohydrate storage in the tuber.

Figures 1 and 2 show that CSC (\%) estimates from the three estimation Equations (1), (2), and (3) adopted in the underwater weight method did not differ significantly within each sample size (3 $\mathrm{kg}$ and $5 \mathrm{~kg}$ samples), $\mathrm{p}<0.05$. However, significant differences were detected between CSC (\%) estimates of the two sample sizes (3 $\mathrm{kg}$ vs $5 \mathrm{~kg}$ sample, Figure 3) $(\mathrm{p}<0.05)$. These differences in CSC $(\%)$ estimates due to sample size disagree with the findings of Sungzikaw (2008) who detected insignificant differences in CSC (\%) estimates due to changing the size of cassava tuber samples from $1 \mathrm{~kg}$ to $3 \mathrm{~kg}$, and $3 \mathrm{~kg}$ to $5 \mathrm{~kg}$. On the other hand, in determining the dry matter content (DMC) of cassava tubers using specific gravity method, Teye et al. (2011) reported differences in DMC due to differences in specific gravities obtained from different tuber portions (top, middle and bottom). This could, therefore, explain the differences we detected between estimates derived from different sample sizes since not all treatments we tested yielded enough tubers for us to draw $5 \mathrm{~kg}$ samples and in some cases even $3 \mathrm{~kg}$ samples, thus, forcing us to rely on portions of the tubers other than the middle.

Figure 4 shows a comparison between the average CSC (\%) estimates from contrasting sample sizes ( $3 \mathrm{~kg}$ vs 5 $\mathrm{kg}$ ) and methods or estimation procedures (the Underwater Weight Method vs the Megazyme Total Starch Procedure). It was observed that the Megazyme Total Starch Procedure had relatively higher CSC (\%) than the Underwater Weight Method and all estimates obtained from the three estimation Equations (1), (2), and (3) regardless the sample size. This suggests that both the Underwater Weight Method and the estimation Equations (1), (2), and (3) underestimate the actual CSC (\%) when compared with the Megazyme Total Starch Procedure. Furthermore, when the Underwater Weight Method is used, the actual CSC (\%) may be underestimated even further if a $5 \mathrm{~kg}$ sample is used in place of that of $3 \mathrm{~kg}$. This, therefore, suggests that these estimation equations deserve further review, and that, if the Underwater Weight Method is to be used, CSC estimates close to the actual estimate can be obtained if portions of the tuber other than the middle are avoided.

Figure 5 shows cassava $\mathrm{HCN}$ concentration as influenced by different combinations of contrasting $\mathrm{N}$, $\mathrm{P}$, and $\mathrm{K}$ fertilizer rates, with cassava $\mathrm{HCN}$ concentration ranging from $46.0 \mathrm{mg}$ (treatment 3: 0-60-0 kg/ha N-P $\mathrm{P}_{2} \mathrm{O}_{5}-\mathrm{K}_{2} \mathrm{O}$ ) to $95.2 \mathrm{mg}$ (treatment 4: 0-0-150 kg/ha N- $\mathrm{P}_{2} \mathrm{O}_{5}-\mathrm{K}_{2} \mathrm{O}$ ) per $100 \mathrm{~g} \mathrm{dw}$ (Table 1). These numbers agree with the typical level of $\mathrm{HCN}$ reported to be present in cassava tubers (0.1 to 155 (Cardoso et al., 2005) and/or up to 200 mg per $100 \mathrm{~g} \mathrm{dw}$ (European Food Safety Authority, 2009)). This, therefore, suggests that, like a normal cassava tuber, prior to its consumption, a rigorous tuber processing should be undertaken in order to bring its $\mathrm{HCN}$ concentration to the safe limit of $1 \mathrm{mg}$ per $100 \mathrm{~g}$ as set by the World Health Organization (FAO/WHO, 1991).

Despite the need to lower the concentration of HCN in the tubers, it was observed that tuber HCN concentration did not differ significantly due to fertilizer addition ( $p>0.05$ ), which disagrees with de Bruijn (1973) who in studying the factors influencing cyanogenesis, found that cassava tuber HCN concentration increased with N, decreased with K, and did not change with $\mathrm{P}$ fertilization. Likewise, the Caribbean Agricultural Research and Development Institute (1992) reported higher cassava tuber HCN concentration and bitterness due to increased $\mathrm{N}$ addition as compared to that of $\mathrm{K}$. It is likely that no significant differences in the HCN concentration present in the tubers were detected with the addition of N, P, K fertilizer due to the large variability in the data (LSD = 42.11, Table 1) which is believed to have occurred due to several biotic and abiotic factors whose impacts on the experiment could not be controlled. This includes (1) a predominantly high water table throughout the cropping season (cassava is very susceptible to waterlogging (FAO, 2013)), and (2) lack of disease-free planting material of good quality (consistent size) - a major limiting factor to high tuber yields in Africa (FAO, 2013).

Field observations suggest that these factors may have contributed to the overall variability and therefore few significant differences not only in the tuber HCN data but and the CSC response to added fertilizer (Table 1). 
Due to limited availability of disease-free planting material, stem cuttings of different sizes taken from the top (green) and bottom (high lignin) portions of plants were used so that a plant density equivalent to 10,000 plants per ha could be met. As several studies observed, stem cuttings taken from portions of the plant other than the central part dehydrate very quickly, produce less vibrant shoots, and are susceptible to pests and diseases. As a result, their growth and productivity may be poor (James et al., 2000; Eke-Okoro et al., 1999; FAO, 2013) and diminish tuber quality. During the study period, rainfall was unevenly distributed with more rainfall occurring during the first two to three months after planting and again at the end of the study period. Overall, the site received a total rainfall of $1,831.6 \mathrm{~mm}$ which is approximately $50 \%$ above its typical average $(1,000-1,400 \mathrm{~mm})$. This excessive and sporadic rainfall impacted plant growth and resulted in substantial waterlogging. Coupled with a very shallow water table and a soil texture with low nutrient retention capacity (sand to sandy loam), these conditions may have resulted in nutrient $(\mathrm{K})$ leaching from the soil and also favored denitrification. Additionally, in contrast to local practices, land preparation did not include tilling the plots (no-till) and building bunds prior to planting. As a result, the belowground part of the plant (tubers) remained near the water table during most of the cropping season, resulting in inefficient fertilizer/nutrient use by the crop and limited tuber growth and development. Another factor that may have contributed to the lack of CSC and tuber HCN response to added fertilizer is the fact that there were very limited options in terms of experimental sites. Site selection was based on the availability of land suitable for cultivating cassava in the study region. At harvest, it was realized that the site had been used for charcoal production in the past, a common practice in Milha-14. As several studies demonstrate, charcoal can negatively impact nutrient availability in the soil (Steiner et al., 2008; Steiner et al., 2009; Chintala et al., 2013; Chintala et al., 2014) thus resulting in low quality tubers.

Site variability, depth to water table, and inconsistency on stem cutting quality (size and thickness) all may have impacted the overall CSC and tuber HCN response to added fertilizer. 
Table 1. Summary of cassava starch content (\%) and cyanide (HCN) concentration in dry weight basis. Values in parentheses represent the standard error of the mean

\begin{tabular}{|c|c|c|c|c|c|c|c|c|c|c|c|}
\hline \multirow{3}{*}{\multicolumn{3}{|c|}{$\begin{array}{l}\text { Fertilizer } \\
\text { Combination } \\
\text { in kg per ha }\end{array}$}} & \multirow{4}{*}{ 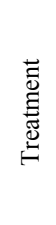 } & \multicolumn{7}{|c|}{ Cassava Starch Content (\%) } & \multirow{4}{*}{$\begin{array}{l}\mathrm{HCN} \text { in } \\
\mathrm{mg} \text { per } 100 \\
\mathrm{~g}\end{array}$} \\
\hline & & & & \multicolumn{6}{|c|}{ Commercial Estimation Procedure ${ }^{(b)}$} & \multirow{3}{*}{$\begin{array}{l}\text { Megazyme } \\
\text { Total Starch } \\
\text { Procedure } \\
\text { (a) }\end{array}$} & \\
\hline & & & & \multicolumn{3}{|c|}{3 kg Sample ${ }^{(a)}$} & \multicolumn{3}{|c|}{5 kg Sample ${ }^{(b)}$} & & \\
\hline $\mathrm{N}$ & $\mathrm{P}_{2} \mathrm{O}_{5}$ & $\mathrm{~K}_{2} \mathrm{O}$ & & $\mathrm{EE} \mathrm{I}^{(\mathrm{a})}$ & $\mathrm{EE} \mathrm{II}^{(\mathrm{a})}$ & $\mathrm{EE} \mathrm{III}^{(\mathrm{a})}$ & $\mathrm{EE} \mathrm{I}^{(a)}$ & $\mathrm{EE} \mathrm{II}^{(\mathrm{a})}$ & $\mathrm{EE} \mathrm{III}^{(\mathrm{a})}$ & & \\
\hline 0 & 0 & 0 & 1 & $60.7(2.3) \mathrm{a}$ & $62.6(2.4) \mathrm{a}$ & $61.3(2.4) \mathrm{a}$ & $24.9(0.5) \mathrm{ab}$ & $25.6(0.5) \mathrm{ab}$ & $25.2(0.5) \mathrm{ab}$ & $72.5(1.0) \mathrm{ab}$ & $76.3(20.4) \mathrm{a}$ \\
\hline 60 & 0 & 0 & 2 & $46.9(5.8) \mathrm{a}$ & $48.5(6.1) \mathrm{a}$ & $47.5(5.9) \mathrm{a}$ & ND & ND & ND & $71.9(1.6) \mathrm{b}$ & $56.8(8.3) \mathrm{a}$ \\
\hline 0 & 60 & 0 & 3 & $63.9(6.6) \mathrm{a}$ & $65.9(6.8) \mathrm{a}$ & $64.6(6.7) \mathrm{a}$ & $36.9(1.1) \mathrm{a}$ & $37.8(1.2) \mathrm{a}$ & $37.1(1.2) \mathrm{a}$ & $72.2(0.5) \mathrm{ab}$ & $46(15.5) \mathrm{a}$ \\
\hline 0 & 0 & 150 & 4 & $54.4(6.6) \mathrm{a}$ & $55.9(6.9) \mathrm{a}$ & $54.9(6.7) \mathrm{a}$ & $33.4(4.5) \mathrm{a}$ & $34.2(4.8) \mathrm{a}$ & $33.6(4.6) \mathrm{a}$ & $73.3(1.1) \mathrm{ab}$ & $95.2(5.6) \mathrm{a}$ \\
\hline 0 & 60 & 150 & 5 & $59.2(3.2) \mathrm{a}$ & $60.9(3.4) \mathrm{a}$ & $59.8(3.3) \mathrm{a}$ & $36.8(1.5) \mathrm{a}$ & $37.7(1.6) \mathrm{a}$ & $37.0(1.6) \mathrm{a}$ & $70.8(1.5) \mathrm{b}$ & $70.7(21.5) \mathrm{a}$ \\
\hline 25 & 60 & 150 & 6 & $63.5(2.4) \mathrm{a}$ & $65.5(2.5) \mathrm{a}$ & $64.1(2.4) \mathrm{a}$ & $36.6(1.4) \mathrm{a}$ & $37.5(1.4) \mathrm{a}$ & $49.1(1.4) \mathrm{a}$ & ND & $74(22.4) \mathrm{a}$ \\
\hline 50 & 60 & 150 & 7 & $47.7(5.7) \mathrm{a}$ & $48.8(5.9) \mathrm{a}$ & $47.9(5.8) \mathrm{a}$ & $42.5(3.2) \mathrm{a}$ & $43.4(3.4) \mathrm{a}$ & $42.7(3.3) \mathrm{a}$ & ND & $71.2(15.6) \mathrm{a}$ \\
\hline 75 & 60 & 150 & 8 & $57.5(3.3) \mathrm{a}$ & $59.2(3.5) \mathrm{a}$ & $58.0(3.4) \mathrm{a}$ & $22.1(3.1) \mathrm{ab}$ & $22.6(3.3) \mathrm{b}$ & $22.2(3.2) \mathrm{ab}$ & ND & $64.7(21.7) \mathrm{a}$ \\
\hline 100 & 60 & 150 & 9 & $52.1(5.8) \mathrm{a}$ & $53.6(6.1) \mathrm{a}$ & $52.6(5.9) \mathrm{a}$ & $34.3(1.0) \mathrm{a}$ & $35.1(1.1) \mathrm{a}$ & $34.5(1.1) \mathrm{a}$ & ND & $67.9(18.8) \mathrm{a}$ \\
\hline 60 & 0 & 150 & 10 & $44.2(1.3) \mathrm{a}$ & 45.5 (1.4)a & $44.6(1.3) \mathrm{a}$ & $24.1(0.2) \mathrm{ab}$ & $24.7(0.3) \mathrm{b}$ & $24.3(0.2) \mathrm{ab}$ & ND & $63.9(18.6) \mathrm{a}$ \\
\hline 60 & 30 & 150 & 11 & $47.1(1.6) \mathrm{a}$ & $48.6(1.7) \mathrm{a}$ & $47.6(1.6) \mathrm{a}$ & $36.1(2.1) \mathrm{a}$ & $36.9(2.2) \mathrm{a}$ & $36.3(2.2) \mathrm{a}$ & ND & $72.3(5.1) \mathrm{a}$ \\
\hline 60 & 60 & 150 & 12 & $59.5(2.2) \mathrm{a}$ & $61.3(3.1) \mathrm{a}$ & $60.1(3.0) \mathrm{a}$ & ND & ND & ND & $73.9(0.6) \mathrm{ab}$ & $62.4(12.7) \mathrm{a}$ \\
\hline 60 & 90 & 150 & 13 & $61.4(1.6) \mathrm{a}$ & $63.3(1.7) \mathrm{a}$ & $62.0(1.6) \mathrm{a}$ & $48.6(0.7) \mathrm{a}$ & $49.8(0.7) \mathrm{a}$ & $48.9(0.7) \mathrm{a}$ & ND & $76.3(6.4) \mathrm{a}$ \\
\hline 60 & 60 & 0 & 14 & $57.3(1.3) \mathrm{a}$ & $58.9(1.4) \mathrm{a}$ & $57.8(1.4) \mathrm{a}$ & $36.8(10.9) \mathrm{a}$ & $37.4(11.4) \mathrm{a}$ & $36.9(11.1) \mathrm{a}$ & ND & $70.2(16.1) \mathrm{a}$ \\
\hline 60 & 60 & 30 & 15 & $63.1(4.3) \mathrm{a}$ & $65.1(4.5) \mathrm{a}$ & $63.8(4.3) \mathrm{a}$ & $29.9(0.6) \mathrm{ab}$ & $25.6(14.8) b$ & $25.1(0.6) \mathrm{ab}$ & ND & $50.7(19.8) \mathrm{a}$ \\
\hline 60 & 60 & 60 & 16 & $59.6(2.9) \mathrm{a}$ & $61.4(3.0) \mathrm{a}$ & $60.2(2.9) \mathrm{a}$ & $29.9(0.4) \mathrm{ab}$ & $25.6(0.4) \mathrm{b}$ & $25.2(0.4) \mathrm{ab}$ & $72.7(1.5) \mathrm{ab}$ & $56.8(9.8) \mathrm{a}$ \\
\hline 60 & 60 & 90 & 17 & $63.8(1.5) \mathrm{a}$ & $65.9(1.6) \mathrm{a}$ & $64.5(1.6) \mathrm{a}$ & $37.8(37.8) \mathrm{a}$ & $38.8(0.3) \mathrm{a}$ & $38.1(0.3) \mathrm{a}$ & ND & $62.7(17.2) \mathrm{a}$ \\
\hline 60 & 60 & 120 & 18 & $56.9(7.5) \mathrm{a}$ & $58.6(7.9) \mathrm{a}$ & $57.4(7.6) \mathrm{a}$ & $40.0(40) \mathrm{a}$ & $41.1(3.1) \mathrm{a}$ & $40.4(3.2) \mathrm{a}$ & ND & $53.3(16.3) \mathrm{a}$ \\
\hline 60 & 60 & 150 & 19 & $60.8(0.9) \mathrm{a}$ & $62.7(0.9) \mathrm{a}$ & $61.4(0.9) \mathrm{a}$ & $36.8(36.8) \mathrm{a}$ & $37.8(0.2) \mathrm{a}$ & $37.1(0.2) \mathrm{a}$ & $76.8(0.0) \mathrm{a}$ & $57.4(23.7) \mathrm{a}$ \\
\hline 60 & 60 & 180 & 20 & $53.1(5.7) \mathrm{a}$ & $54.6(6.0) \mathrm{a}$ & $53.6(5.8) \mathrm{a}$ & $33.1(33.1) \mathrm{a}$ & $33.8(4.4) \mathrm{a}$ & $33.7(4.5) \mathrm{a}$ & ND & $62.5(14.3) \mathrm{a}$ \\
\hline LSD & & & & 20.5 & 21.3 & 20.8 & 32.3 & 33.2 & 32.6 & 6.0 & 42.1 \\
\hline
\end{tabular}

Note. $\mathrm{EE}=$ Estimation Equation: EEI: $\mathrm{CSC}=(\mathrm{SG}-1.00906) / 0.004845$ (Sungzikaw, 2008), EEII: $\mathrm{CSC}=(\mathrm{SG}-$ 1.01506)/0.0046051 (ISI, 1999), EE III: CSC $=210.8 * S G-213.4$ (Khanthavong et al., 2012), and ND = No Data available. Means followed by the same letter in the same column are equal at 5\% level (LSD). Estimation procedures, sample sizes and EEs followed by the same letter in the same row yielded estimates that are equal at $5 \%$ level (LSD). 


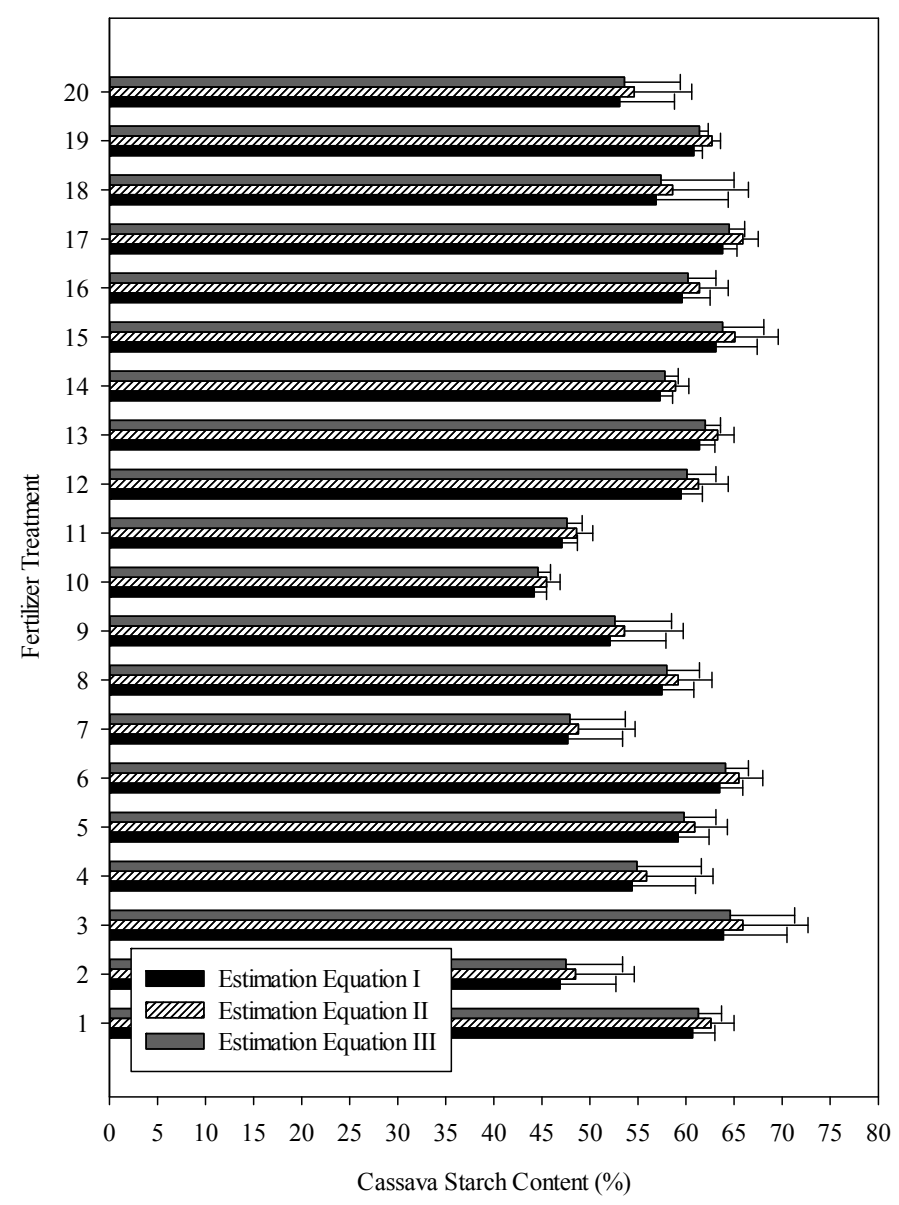

Figure 1. Cassava starch content (CSC) estimation from $3 \mathrm{~kg}$ tuber sample in dry weight basis. CSC estimates (X axis) from all three estimation equations are presented for each fertilizer combination (Y axis). Error bars represent the standard error of the mean. Fertilizer treatments one through twenty are different fertilizer combinations (Table 1) 


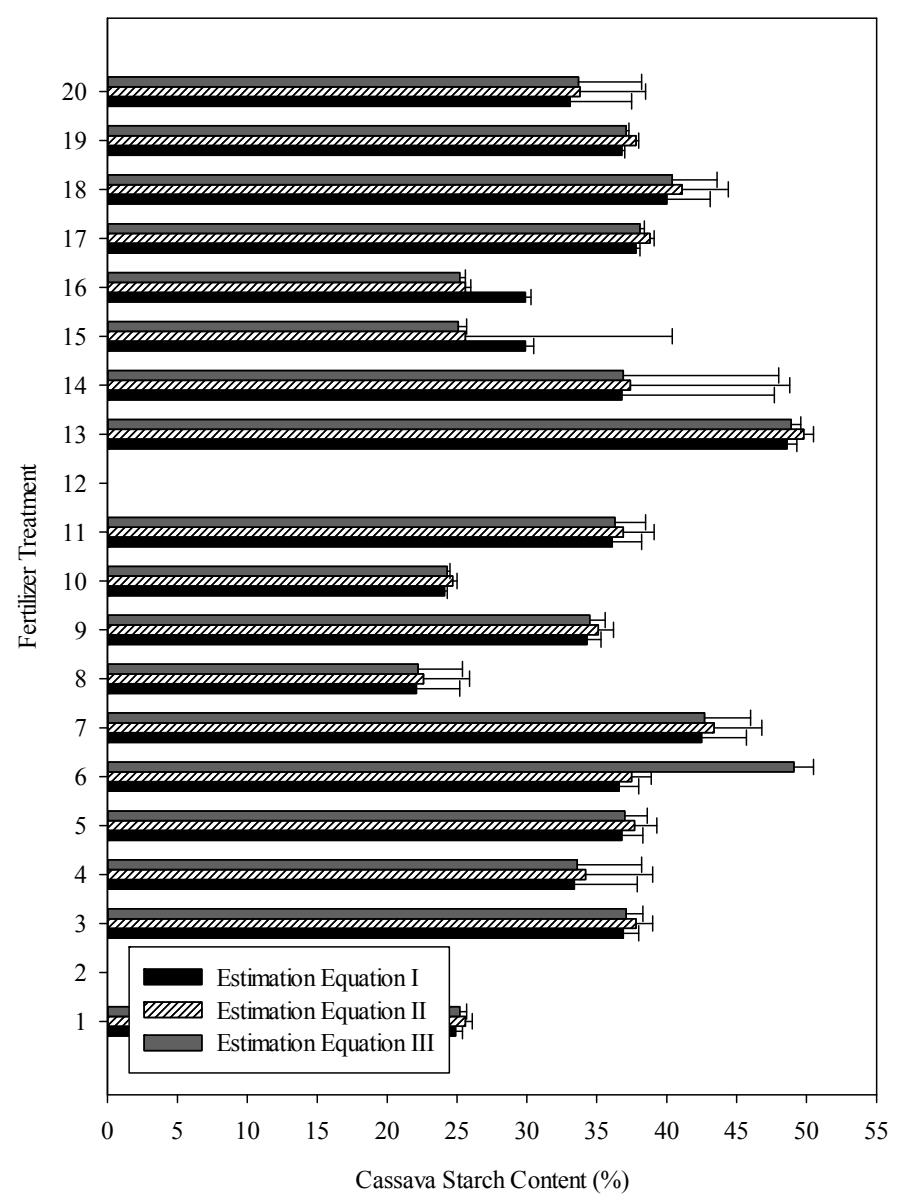

Figure 2. Cassava starch content (CSC) estimation from $5 \mathrm{~kg}$ tuber sample in dry weight basis. CSC estimates (X axis) from all three estimation equations are presented for each fertilizer combination (Y axis). Error bars represent the standard error of the mean. Fertilizer treatments one through twenty are different fertilizer combinations (Table 1). Treatments 2 and 12 did not yield enough tubers to estimate CSC from a $5 \mathrm{~kg}$ sample 


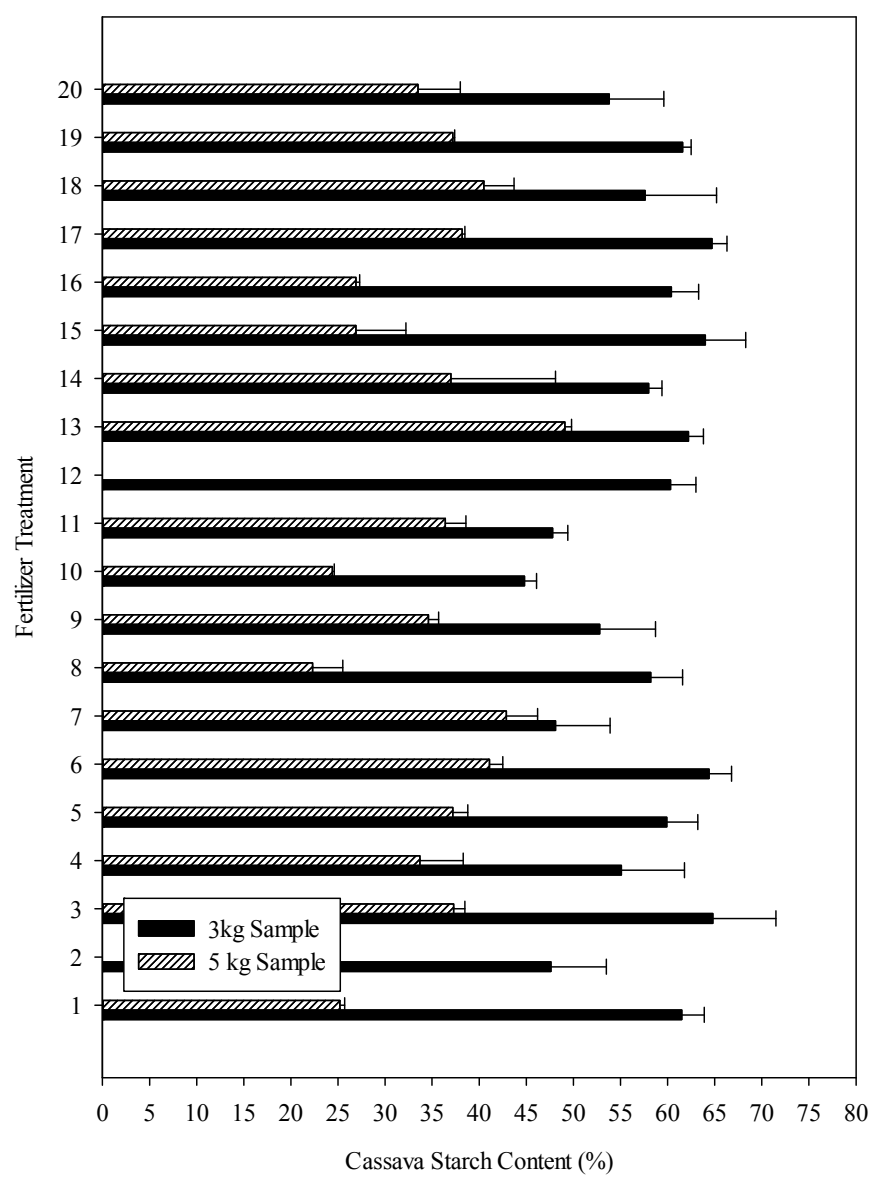

Figure 3. Comparison of cassava starch content (CSC) estimations from contrasting tuber sample sizes in dry weight basis. Average CSC estimates (X axis) from all three estimation equations and two sample sizes ( $3 \mathrm{~kg}$ and $\mathrm{kg}$ ) are presented for each fertilizer combination ( $\mathrm{Y}$ axis). Error bars represent the standard error of the mean. Fertilizer treatments one through twenty are different fertilizer combinations (Table 1). Treatments 2 and 12 did not yield enough tubers to estimate CSC from a $5 \mathrm{~kg}$ sample 


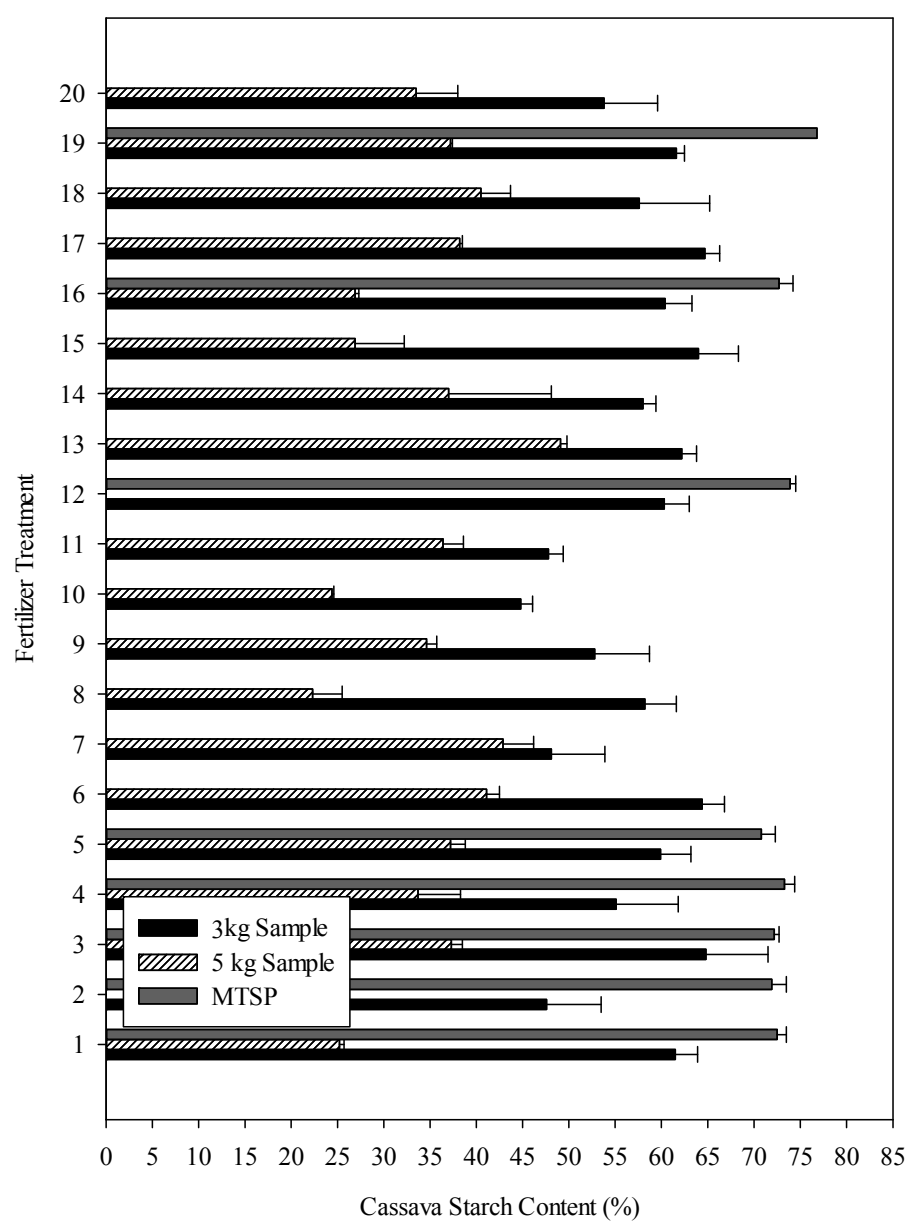

Figure 4. Comparison of cassava starch content (CSC) estimations from contrasting tuber sample sizes and procedures in dry weight basis. Average CSC estimates (X axis) from all three estimation equations and estimation procedures are presented for each fertilizer combination (Y axis). Error bars represent the standard error of the mean. Fertilizer treatments one through twenty are different fertilizer combinations (Table 1). Treatments 2 and 12 did not yield enough tubers to estimate CSC from a $5 \mathrm{~kg}$ sample. MTSP stands fror Megazyme Total Starch Procedure. The MTSP was run on a total of eight samples randomly selected from each plot 


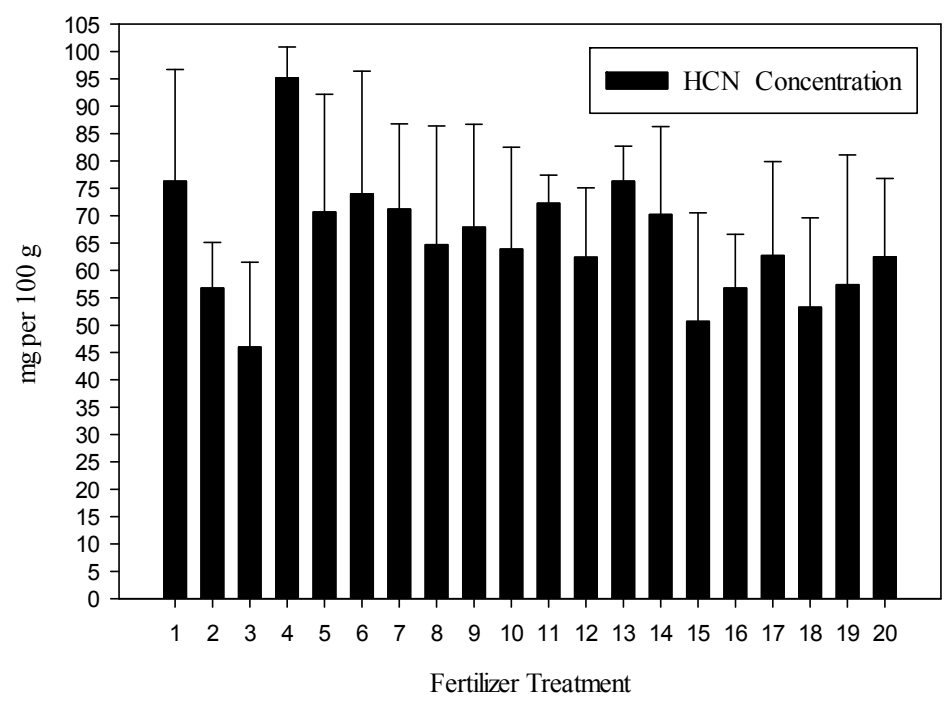

Figure 5. Cassava tuber cyanide (HCN) concentration in dry weight basis. Error bars represent the standard error of the mean. Fertilizer treatments one through twenty are different fertilizer combinations (Table 1)

\section{Conclusions}

Our findings suggest that cassava starch content (\%) is influenced by N, P and K fertilizer rate combination, but that these differences may be confounded by sampling and content determination procedures. CSC estimated using Equations (1), (2), and (3) (used in the Underwater Weight Method) did not differ significantly; however, all three estimation Equations (1), (2), and (3) used in the Underwater Weight Method underestimated actual CSC compared with the results obtained using the Megazyme Total Starch Procedure. On the other hand, it was observed that all estimation Equations (1), (2), and (3) provide CSC estimates that approximate those obtained using the Megazyme Total Starch Procedure if a sample size of $3 \mathrm{~kg}$ is used, thus suggesting that famers lacking resources should use a $3 \mathrm{~kg}$ sample size for estimating the market price of their starch. It was also observed that cassava tuber cyanide $(\mathrm{HCN})$ is unaffected by $\mathrm{N}, \mathrm{P}$ and $\mathrm{K}$ fertilizer rate combination. This suggests that it is likely that cassava $\mathrm{HCN}$ is more sensitive to the type of cultivar (bitter or sweet) and crop physiology rather than the nutrient-poor conditions under which the crop is grown. Thus, adoption of low HCN cassava varieties and a more efficient use of existing methods to lowering cassava tuber HCN concentration such as blanching and fermentation should be considered for minimizing the risks of human exposure to cassava HCN and potential poisoning. It is also clear from this analysis that the three estimation Equations (1), (2), and (3) used for estimating actual CSC when the Underwater Weight Method was used deserve further attention. The response curves and overall statistical analysis suggest that high starch production at Milha-14 can be achieved with a combined fertilizer addition of $0-60-0 \mathrm{~kg} / \mathrm{ha} \mathrm{N}-\mathrm{P}_{2} \mathrm{O}_{5}-\mathrm{K}_{2} \mathrm{O}$ without affecting the concentration of $\mathrm{HCN}$ present in the tubers.

\section{References}

Benesi, I. R. M. (2005). Characterisation of Malawian cassava germplasm for diversity, starch extraction and its native and modified properties (Ph.D. thesis). University of the Free State. Retrieved June 3, 2014, from http://etd.uovs.ac.za/ETD-db/theses/available/etd-07042006-090839/unrestricted/BENESIIRM.pdf

Braidotti, G. (2011). Cassava, cyanide and Konzo disease. Focus on NGOs. Retrieved December 19, 2013, from http://aciar.gov.au/files/node/13748/cassava_cyanide_and_konzo_disease_75809.pdf

Cardoso, A. P., Mirione, E., Ernesto, M., Massaza, F., Cliff, J., Hare, M. R., \& Bradbury, J. H. (2005). Processing of cassava roots to remove cyanogens. Journal of Food Composition and Analysis, 18(2005), 451-460. http://dx.doi.org/10.1016/j.jfca.2004.04.002

Caribbean Agricultural Research and Development Institute (CARDI). (1992). Commercial Cassava Production. Factsheet. Frances Chandler. Order no.: CP-F/ 16-89.

Chintala, R., McDonald, L. M., \& Bryan, W. B. (2012a). Effect of soil water and nutrients on productivity of 
Kentucky bluegrass systems in acidic soils. Journal of Plant Nutrition, 35, 288-303. http://dx.doi.org/10.1080/01904167.2012.636131

Chintala, R., McDonald, L. M., \& Bryan, W. B. (2012b). Optimization of water potential and nutrient levels for Kentucky bluegrass-white clover mixture on acidic soils. Biotechnology, Agronomy, Society and Environment, 16, 167-177.

Chintala, R., Mollinedo, J., Schumacher, T. E., Malo, D. D., Papiernik, S., Clay, D. E., ... Gulbrandson, D. W. (2013). Nitrate sorption and desorption by biochars produced from microwave pyrolysis. Microporous and Mesoporous Materials, 179, 250-257. http://dx.doi.org/10.1016/j.micromeso.2013.05.023

Chintala, R., Schumacher, T. E., McDonald, L. M., Clay, D. E., Malo, D. D., Clay, S. A., ... Julson, J. L. (2014). Phosphorus sorption and availability in biochars and soil biochar mixtures. CLEAN-Soil Air Water, 42(5), 626-634. http://dx.doi.org/10.1002/clen.201300089

De Bruijn, G. H. (1973). The cyanogenic character of cassava (Manihot esculenta). Chronic cassava toxicity (pp. 43-48). Proceedings of an interdisciplinary workshop. London, England: Mt. Develop. Res. Centre Monogr. IDRC-OLOe.

Dias, P. (2012). Analysis of incentives and disincentives for cassava in Mozambique. Technical notes series, MAFAP, FAO, Rome. Retrieved June 19, 2014, from http://www.fao.org/fileadmin/templates/mafap/docum ents/technical_notes/MOZAMBIQUE/MOZAMBIQUE_Technical_Note_CASSAVA_EN_Oct2012.pdf

Eke-Okoro, O. N., Okereke, O. U., \& Okele, J. E. (1999). Effects of weather change and planting set on growth and productivity of cassava in southeastern Nigeria. African Journal of Root and Tuber Crops, 3(2), 34-38.

El-Sharkawy, M. A. (2004). Cassava biology and physiology. Plant Molecular Biology, 56, $481-501$. http://dx.doi.org/10.1007/s11103-005-2270-7

Essers, S. (1988). Bitter cassava as a drought resistant crop: A case in Mozambique. ILEIA Newsletter, 4(4). Retrieved August 19, 2014, from http://www.agriculturesnetwork.org/magazines/global/enhancing-drylandagriculture/bitter-cassava-as-a-drought-resistant-crop-a-case

European Food Safety Authority (EFSA). (2009). EFSA SCIENTIFIC COOPERATION (ESCO) REPORT: EFSA Compendium of botanicals that have been reported to contain toxic, addictive, psychotropic or other substances of concern. EFSA Journal, 7(9), 281. Retrieved December 4, 2014, from http://www.efsa.europa.eu/en/scdocs/doc/280rax1.pdf

FAO. (1977). Cassava processing. FAO Corporate Document Repository (p. 17). ISBN 92-5-100171-5. Retrieved December 3, 2014, from http://www.fao.org/docrep/X5032E/x5032E01.htm

FAO. (2006). Starch market adds value to cassava. Retrieved December 2, 2014, from http://www.fao.org/ag/magazine/pdf/0610-1.pdf

FAO. (2011). Food Outlook: Global Market Analysis. Retrieved from http://www.fao.org/docrep/014/a1981e/al981e00.pdf

FAO. (2013). Save and Grow: Cassava. A Guide to Sustainable Production Intensification, Rome. E-ISBN 978-92-5-107642-2. Retrieved from http:/www.fao.org/docrep/018/i3278e/i3278e.pdf

FAO/WHO. (1991). Joint FAO/WHO Food Standards Programme. Codex Alimentarius Comission XII (Supplement 4). FAO, Rome, Italy.

Gardner, F. P., Pearce, R. B., \& Mitchell, R. L. (1985). Physiology of Crop Plants. Iowa State University Press.

Gwarizimba, V. (2009). Cotton and cassava seed systems: Malawi, Mozambique and Zambia (p. 7, p. 11, p. 28). FAO. All Agricultural Commodities Programme, Zimbabwe.

Hillocks, R. J., Thresh J. M., \& Bellotti, A. C. (2002a). Cassava: Biology, Production and Utilization. The origins and taxonomy of cassava (Chapter 1, pp. 1-11). CABI Publishing. New York, USA. ISBN 0851995241. http://dx.doi.org/10.1079/9780851995243.0000

Hillocks, R. J., Thresh, J. M., Tomas, J., Botao, M., Macia, R., \& Zavier, R. (2002b). Cassava brown streak disease in northern Mozambique. International Journal of Pest Management, 48(3), 178-181. http://dx.doi.org/10.1080/09670870110087376

International Starch Institute (ISI). (1999). ISI 13-2e Determination of starch in tubers by underwater weight. Science Park Aarhus, Denmark.

James, B., Yaninek, J., Tumanteh, A., Maroya, N., Dixon, A., Salawu, R., \& Kwarteng, J. (2000). Starting a 
Cassava Farm. IPM Field Guide for Extension Agents, Nigeria. ISBN 978-131-173-8. Retrieved June 4, 2014, from http://www.infonet-biovision.org/res/res/files/1855.Starting.pdf

Khanthavong, P., Phattarakul, N., Jamjod, S., Aye, T. M., \& Rerkasem, B. (2012). Effect of Stake Priming with Complete Nutrient Solution on Cassava Root and Starch Yield. CMU. J. Nat. Sci. Special Issue on Agricultural and Natural Resources, 11(1), 75.

Lambri, M., Fumi, M. D., Roda, A., \& De Faveri, D. M. (2013). Improved processing methods to reduce the total cyanide content of cassava roots from Burundi. Afr. J. Biotechnol, 12(19), 2685-2691.

Magnuson, B. (1997). Cyanogenic Glycosides. Department of Food Science and Toxicology, University of Idaho. Retrieved from http://extoxnet.orst.edu/faqs/natural/cya.htm

Maria, R. M., \& Yost, R. (2006). A survey of soil fertility status of four agro-ecological zones of Mozambique. Soil Science, 171(11), 902-914. http://dx.doi.org/10.1097/01.ss.0000228058.38581.de

Megazyme International Ireland (MII). (2011). Megazyme Total Starch Assay Procedure (Amyloglucodsidase/a-Amylase Method). AOAC Method 996.11 and AACC Method 76.13 (and improvements). K-TSTA 07/11.

Ministério da Indústria e Comércio/Direcção Nacional do Comércio (MIC/DNC). (2007). Sub-Sector Strategic Study on Cassava: Cassava Development Strategy for Mozambique (2008-2012) (Vol. 1).

Ministry of Agriculture \& Fisherie (MAF). (1996). Agroecological Zones and Production Systems. Working Document 2/b, Program of Investment in Agricultural Extension, Process of the Formulation of Proagri. Maputo, Mozambique; Ministry of Agriculture and Fisheries.

Nambisan, B. (2011). Strategies for elimination of cyanogens from cassava for reducing toxicity and improving food safety. Food Chem. Toxicol., 49, 690-693. http://dx.doi.org/10.1016/j.fct.2010.10.035

Nwosu, L. A., \& Onofeghara, F. A. (1991). A comparison of cyanide accumulation, leaf retention and Linamarase activity of cassava varieties during water stress (pp. 187-193). Tropical Root Crops in a Developing Economy: Proceeding of the ninth Symposium of the International Society for Tropical Root Crops held in Accra, Ghana. October 20-26 1991.

Promar Consulting. (2011). Subsistence Agriculture Study. The Cassava Industries in Mozambique and Tanzania: Production, processing, distribution and consumption of cassava and its related policy challenges ( $\mathrm{pp}$. 79-81). Retrieved from http://www.apip-apec.com/ja/good-practices/files/The_Cassava_Industries_in_Moz ambique_and_Tanzania-2011.pdf

Rosenthal, D. M., \& Ort, D. R. (2011). Examining Cassava's Potential to Enhance Food Security Under Climate Change. Tropical Plant Biology, 4(3-4), 145-250. http://dx.doi.org/10.1007/s12042-011-9086-1

Sarkiyayi, S., \& Agar, T. M. (2010). Comparative analysis on the nutritional and anti-nutritional contents of the sweet and bitter cassava varieties. Adv. J. Food Sci. Technol., 2, 328-334.

Saunders, D. A. (2012). When plants bite back: A broadly applicable method for the determination of cyanogenic glycosides as hydrogen cyanide in plant-based foodstuffs. Chemistry in New Zealand. Retrieved December 4, 2012, from http://nzic.org.nz/CiNZ/articles/2012/CiNZ\%20OCT\%202012_Saunders.pdf

Soil Survey Staff. (2010). Keys to Soil Taxonomy (11th ed.). USDA - Natural Resources Conservation Service, Washington DC 338.

Steiner, C., Garcia, M., \& Zech, W. (2009). Effects of Charcoal as Slow Release Nutrient Carrier on N-P-K Dynamics and Soil Microbial Population: Pot Experiments with Ferrasol Substrate. In W. I. Woods et al. (Eds.), Amazonian Dark Earths: Wim Sombroek's cisio (pp. 325-338). Springer Science \& Business Media B.V. http://dx.doi.org/10.1007/978-1-4020-9031-8_17

Steiner, C., Glaser, B., Teixeira, W. G., Lehmann, J., Blum, W. E. H., \& Zech, W. (2008). Nitrogen retention and plant uptake on a highly weathered central Amazonian Ferralsol amended with compost and charcoal. $J$. Plant Nutr. Soil Sci., 171, 893-899. http://dx.doi.org/10.1002/jpln.200625199

Sungzikaw, S. (2008). Measurements of starch content in cassava. Workshop on metrology in food safety, agricultural products and product safety, Hangzhou, China.

Teye, E., Asare, A. P., Amoah, R. S., \& Tetteh, J. P. (2014). Determination of the dry matter content of cassava (Manihot esculenta, Crantz) tubers using specific gravity method. ARPN Journal of Agriculture and Biological Science. ISSN 1990-6145. Retrieved December 4, 2014, from 
http://www.arpnjournals.com/jabs/research_papers/rp_2011/jabs_1111_332.pdf

Ukaoma, A., \& Ogbonnaya, C. (2013). Effect of inorganic mineral nutrition on tuber yield of cassava (Manihot esculenta Crantz) on marginal ultisol of South Eastern Nigeria. Acad. J. Agric. Res., 1(9), 172-179.

\section{Copyrights}

Copyright for this article is retained by the author(s), with first publication rights granted to the journal.

This is an open-access article distributed under the terms and conditions of the Creative Commons Attribution license (http://creativecommons.org/licenses/by/3.0/). 